\title{
Investigation on the effects of loading pads hardness on the calibration results of force transducers
}

\author{
Ebtisam H. Hassan, R.Hegazy, Gouda M.Mahmoud ${ }^{\mathrm{a} 1}$ \\ ${ }^{I}$ National Institute for standard, Tersa St. Haram Giza, Egypt
}

\begin{abstract}
Résumé. Vous connaissez la pratique dans l'utilisation de la force prouvant instruments tels que les cellules de charge à utiliser des plaquettes de chargement afin de maintenir la sécurité de la cellule de charge de tous les défauts qui peuvent être produites en raison de contact direct entre le corps transducteur de force et le calibrage machine standard et également dans le cas de surcharge accidentelle. La fabrication de la cellule de charge fournit ces plots de chargement par une certaine dureté et la rigidité déterminée en fonction de la capacité de la cellule de charge. Ces tampons de chargement peuvent être perdu, et d'avoir à utiliser d'autres tampons de chargement qui ne sont pas les mêmes propriétés mécaniques par rapport à l'original. Par conséquent, le but de cette étude est d'étudier l'effet de changer les plaquettes de chargement avec différentes valeurs de dureté sur les résultats d'étalonnage des capteurs de force. L'enquête montre qu'il existe des effets significatifs de la dureté de pad de chargement sur les résultats de l'étalonnage où les dureté tampons des résultats plus faibles sont plus faibles que pour les plaquettes de dureté élevés, cela se produit en raison de l'énergie de déformation absorbée dans le cas de pad de dureté inférieure qui tend à forcer les pertes et donc de réduire la force appliquée sur le capteur de force d'étalonnage et la réponse en vertu donc inférieure de celui-ci.
\end{abstract}

\section{Introduction}

The load cell is a transducer to detect load which bears the load directly by load cell itself the load cell should be installed so that the load can be applied vertically to the load cell [1]. The top of the load cell is so spherical that bending moment or distortion is not applied to the load cell so the use of a spherical cap is recommended. The spherical cap is mounted to the top of a compression load cell for accurate transmission of compression loads see figure.1. The in the case of tension load cell Rotary Attachment used to ensures smooth load transmission by eliminating torsion during tension load measurements see figure. 2 [2]. It's required for these loading pads such as Spherical Cap and Rotary Attachment to be rigid enough and have a sufficient hardness to perform the specified application [3]. In the case of losing these accessories it is required to design and fabricate other alternative accessories similar to them . The aim of this research is to investigate the effects of hardness of these alternatives accessories on the response of the under calibration load cells

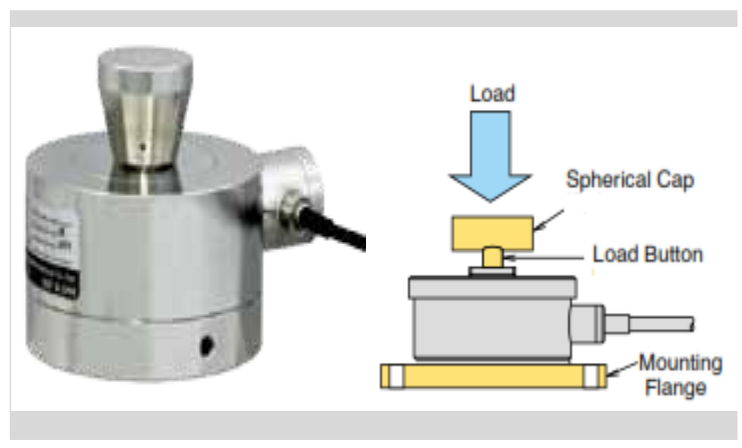

Figure 1. The spherical cap of the compression load cell

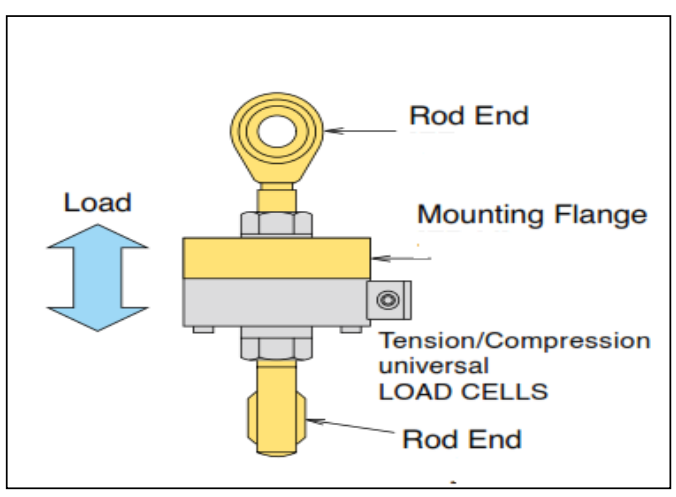

Figure 2. The rotary rod end of the tension load cell

\section{Experimental work}

National institute of standard of Egypt $50 \mathrm{kN}$ dead weight standard machine with relative expanded uncertainty of \pm 0.002 was used .This machine is constructed to apply the calibration load values in $0.5 \mathrm{kN}$ steps over the whole range of the compression. Two reference force transducers with capacities of $5 \mathrm{kN}$ and $10 \mathrm{kN}$ and two samples with different hardness (171HV50 and 249 HV50) were used to conduct this investigation.

\section{Procedure of the investigation}

\footnotetext{
${ }^{\mathrm{a}}$ Corresponding author: goudamohamed15@yahoo.com
} 
The two force transducers were calibrated three times for each in accordance with ASTM E74, the first calibration was done using the normal loading cap and the second one was conducted using the 171HV50 loading cap and the third was done using $249 \mathrm{HV} 50$ and the comparison of the results were done and relative error was calculated.

\section{Results and discussion}

After calibrating the two load cells in accordance with the previous section and relative error was calculated, the results of the investigation were summarized in the following tables and figures.

Table 1.The calibration results of $5 \mathrm{kN}$ load cell using normal cap and 249 HV cap

\begin{tabular}{|c|c|c|c|}
\hline $\begin{array}{c}\text { Steps } \\
(\mathrm{N})\end{array}$ & $\begin{array}{c}\text { Normal cap } \\
(\mathrm{mv} / \mathrm{v})\end{array}$ & $\begin{array}{c}\text { Top loading cap } \\
(\mathrm{mv} / \mathrm{v})\end{array}$ & $\begin{array}{c}\text { Relative error } \\
(\%)\end{array}$ \\
\hline 1.0 & 0.400095 & 0.400085 & 0.0025 \\
\hline 1.5 & 0.600172 & 0.60015 & 0.0037 \\
\hline 2.0 & 0.800326 & 0.800304 & 0.0027 \\
\hline 2.5 & 1.000501 & 1.000457 & 0.0044 \\
\hline 3.0 & 1.200701 & 1.200681 & 0.0017 \\
\hline 3.5 & 1.400935 & 1.400878 & 0.0041 \\
\hline 4.0 & 1.601224 & 1.601145 & 0.0049 \\
\hline 4.5 & 1.801541 & 1.8015 & 0.0023 \\
\hline 5.0 & 2.001866 & 2.00178 & 0.0044 \\
\hline
\end{tabular}

Table 2: The calibration results of $5 \mathrm{kN}$ load cell using normal cap and 171 HV cap

\begin{tabular}{|c|c|c|c|}
\hline $\begin{array}{c}\text { Steps } \\
(\mathrm{N})\end{array}$ & $\begin{array}{c}\text { Normal cap } \\
(\mathrm{mv} / \mathrm{v})\end{array}$ & $\begin{array}{c}\text { Top loading cap } \\
(\mathrm{mv} / \mathrm{v})\end{array}$ & $\begin{array}{c}\text { Relative error } \\
(\%)\end{array}$ \\
\hline 1.0 & 0.400065 & 0.400004 & 0.01525 \\
\hline 1.5 & 0.600172 & 0.600082 & 0.01500 \\
\hline 2.0 & 0.800326 & 0.800198 & 0.01600 \\
\hline 2.5 & 1.000501 & 1.000350 & 0.01509 \\
\hline 3.0 & 1.200701 & 1.200520 & 0.01508 \\
\hline 3.5 & 1.400935 & 1.400683 & 0.01799 \\
\hline 4.0 & 1.601224 & 1.600995 & 0.01430 \\
\hline 4.5 & 1.801541 & 1.801276 & 0.01471 \\
\hline 5.0 & 2.001866 & 2.001537 & 0.01644 \\
\hline
\end{tabular}

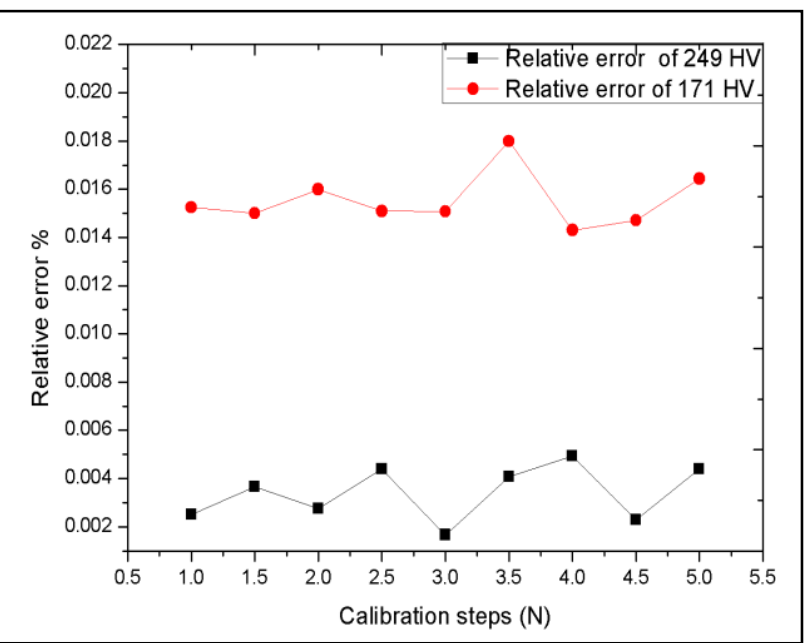

Table 3. The calibration results of $10 \mathrm{kN}$ load cell using normal cap and 249 HV cap

\begin{tabular}{|c|c|c|c|}
\hline $\begin{array}{c}\text { Steps } \\
(\mathrm{N})\end{array}$ & $\begin{array}{c}\text { Normal cap } \\
(\mathrm{mv} / \mathrm{v})\end{array}$ & $\begin{array}{c}\text { Top loading cap } \\
(\mathrm{mv} / \mathrm{v})\end{array}$ & $\begin{array}{c}\text { Relative error } \\
(\%)\end{array}$ \\
\hline 1.0 & 0.200574 & 0.20057 & 0.00199 \\
\hline 2.0 & 0.401155 & 0.401162 & -0.00183 \\
\hline 3.0 & 0.601731 & 0.60174 & -0.00144 \\
\hline 4.0 & 0.802299 & 0.802314 & -0.00191 \\
\hline 5.0 & 1.002821 & 1.002841 & -0.00203 \\
\hline 6.0 & 1.203312 & 1.203335 & -0.00194 \\
\hline 7.0 & 1.403745 & 1.403774 & -0.00204 \\
\hline 8.0 & 1.604136 & 1.604168 & -0.00197 \\
\hline 9.0 & 1.804437 & 1.804473 & -0.00198 \\
\hline 10.0 & 2.004682 & 2.004723 & -0.00203 \\
\hline
\end{tabular}

Figure 3. The effect of loading cap hardness on the calibration results of $5 \mathrm{kN}$

Table 4. The calibration results of $10 \mathrm{kN}$ load cell using normal cap and $171 \mathrm{HV}$ cap

\begin{tabular}{|c|c|c|c|}
\hline $\begin{array}{c}\text { Steps } \\
(\mathrm{N})\end{array}$ & $\begin{array}{c}\text { Normal cap } \\
(\mathrm{mv} / \mathrm{v})\end{array}$ & $\begin{array}{c}\text { Top loading cap } \\
(\mathrm{mv} / \mathrm{v})\end{array}$ & $\begin{array}{c}\text { Relative error } \\
(\%)\end{array}$ \\
\hline 1.0 & 0.200574 & 0.20061 & -0.01795 \\
\hline 2.0 & 0.401155 & 0.401235 & -0.02003 \\
\hline 3.0 & 0.601731 & 0.601843 & -0.01856 \\
\hline 4.0 & 0.802299 & 0.802445 & -0.01824 \\
\hline 5.0 & 1.002821 & 1.00299 & -0.01689 \\
\hline 6.0 & 1.203312 & 1.203503 & -0.01590 \\
\hline 7.0 & 1.403745 & 1.403959 & -0.01522 \\
\hline 8.0 & 1.604136 & 1.604363 & -0.01413 \\
\hline 9.0 & 1.804437 & 1.804673 & -0.01306 \\
\hline 10.0 & 2.004682 & 2.004928 & -0.01225 \\
\hline
\end{tabular}

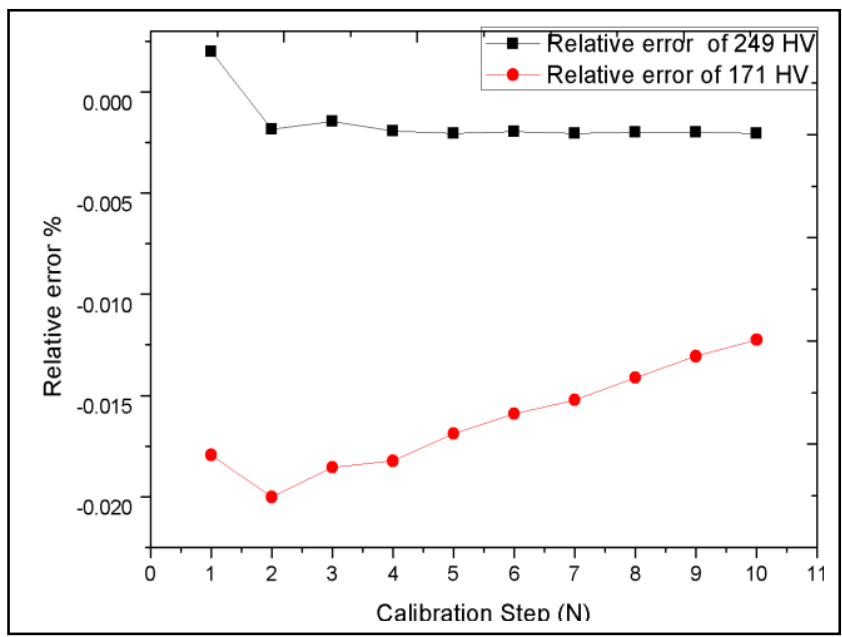


Figure 4. The effect of loading cap hardness on the calibration results of $10 \mathrm{kN}$.

The previous figures and tables showed that there are significant effects of the loading cap hardness on the results of the load cell calibration where the lower hardness pads results are lower than that for the higher hardness pads; also the nearest response to the reference response at normal cap was achieved at higher hardness.

\section{Conclusions}

The investigation shows that there are significant effects of the loading pad hardness on the results of the load cell calibration where the lower hardness pads results are lower than that for the higher hardness pads, this occurs due to the strain energy absorbed in the case of lower hardness pad which tends to force losses and hence lower force applied on the under calibration force transducer and hence lower response of it.

\section{References}

1. Dan Mihai Stefanescu" Handbook of Force Transducers Principles and Components" ISBN: 978-3642-18295-2 (Print) 978-3-642-18296-9

, 2011 Springer-Verlag Berlin Heidelberg

2.http://www.tml.jp/e/product/transducers/general/load_c ell/loadcell option.htm

3. http://www.omega.co.uk/prodinfo/load-cells.htm

4. J. C. Qiao1;*1, Z. P. Xi2;*2, H. P. Tang2, J. Y. Wang2 and J. L. Zhu2 "Compressive Property and Energy Absorption of Porous Sintered Fiber Metals" Materials Transactions, Vol. 49, No. 12 (2008) pp. 2919 to 2921 \#2008 The Japan Institute of Metals 